\title{
Delayed Reaction: UK Maritime Expeditionary Capabilities and the Lessons of the Falklands Conflict.
}

\author{
Dr lan Speller ${ }^{1}$
}

On 2 April 1982 Argentine forces invaded the Falkland Islands ${ }^{2}$ and the next day they occupied South Georgia. The small British garrisons based in both of these locations put up a spirited defense but were forced to capitulate in the face of overwhelming numbers. The Falkland Islands are situated in the South Atlantic, 400 miles to the west of Argentina and 8,000 miles southwest of the United Kingdom (UK). There are two main islands, West Falkland and East Falkland and the only town of any size, Port Stanley, is situated on the latter. South Georgia lies 800 miles to the south-east of the Falklands. To the apparent surprise of the Argentinean ruling Junta, the British dispatched a maritime task force to the South Atlantic intent on restoring British administration to the islands. The first ships of this task force sailed from the UK on 5 April. By 25 April British forces had recaptured South Georgia and on 14 June the Royal Marine commanding British land forces in the Falklands, Major-General Jeremy Moore, accepted the surrender of all Argentine forces in the Islands.

In the aftermath of the conflict there were numerous studies into the conduct of military operations and the lessons that could be drawn. Some commentators concentrated on the legal and diplomatic 'lessons' whilst others took a more military focus. The war provided a rare opportunity to test equipment and tactics in actual combat and much of the resulting literature concentrated on these issues. Equally, the requirement for the British to conduct major expeditionary operations at extended range and beyond the reach of land based air cover caused many to question the overtly Euro-centric focus of UK defense policy and to argue in favor of a new emphasis on what were called 'out of area' capabilities ${ }^{3}$. Prior to the Falklands Conflict British policy had been to rely on forces devoted to North Atlantic Treaty Organization (NATO) contingencies to provide such out of area capabilities. No significant special military capability was retained for operations beyond Europe. This stands in stark contrast to contemporary British defense policy where a considerable emphasis is placed upon expeditionary forces able to operate at extended range. This paper will analyze the impact that the Falklands Conflict had on British approaches to expeditionary warfare, in particular it will concentrate on maritime expeditionary capabilities. It will examine the impact that the war had on British thinking and assess the degree to which contemporary developments have their origins in 'lessons' derived from that experience.

\section{Britannia in Retreat.}

Britain retained interests and responsibilities around the globe after 1945. The UK maintained significant forces beyond Europe in order to protect British interests, support friendly rulers and ensure stability during the difficult process of decolonization. However, the apparent threat posed by the Soviet Union and its allies in

\footnotetext{
${ }^{1}$ The analysis, opinions and conclusions expressed or implied in this article are those of the author and do not necessarily represent the views of the Joint Services Command and Staff College, the UK Ministry of Defence or any other government agency.

${ }^{2}$ In Argentina the Falkland Islands are known as The Malvinas.

${ }^{3}$ In essence 'out of area' meant beyond the NATO region.
} 
Europe was the main focus for British defense policy. In an unprecedented step, Britain retained peacetime conscription after 1945 and in 1954 it agreed to the permanent deployment of four army divisions and a tactical air force in West Germany. The main priority for the Royal Navy was preparation for a third Battle of the Atlantic, this time against Soviet submarines, bombers and surface raiders. Expeditionary capabilities received a very low priority. The costs of this approach were demonstrated in 1956 when the British armed forces were unable to mount a rapid response to the crisis that followed Colonel Nasser's nationalization of the Suez Canal. By the time that the British, with French assistance, were able to launch a combined airborne and amphibious operation to seize the canal, domestic and world opinion had turned decisively against the use of military force. The result was a humiliating political debacle that demonstrated the limits of British power. ${ }^{4}$

The Suez crisis provided added impetus to moves that were already underway to improve Britain's expeditionary capabilities. The defense review conducted by Duncan Sandys in 1957 announced the end of conscription, with a new emphasis on nuclear weapons to maintain the peace in Europe and more mobile and flexible conventional forces to protect British interests overseas. ${ }^{5}$ Conventional war-fighting in Europe was now seen as unlikely and thus shorn of its previous role, the Royal Navy embraced the expeditionary role with enthusiasm. In the years that followed they built the case for a major new capability based around a modern amphibious task group supported by large aircraft carriers, cruisers and a range of escorts and replenishment ships. As a result, the aircraft carriers HMS Bulwark and HMS Albion were converted into helicopter equipped commando carriers (LPH), two new dock landings ships (LPDs) were built to replace the worn-out vessels of the existing Amphibious Warfare Squadron and six new logistic landing ships (LSLs) were ordered. ${ }^{6}$ The 'jewel in the crown' of the navy's plans was the construction of a new generation of large aircraft carriers capable of operating a balanced air group of fighter, strike, airborne-early warning and anti-submarine aircraft. In 1963 the government approved the plans to build the first such ship, codenamed CVA-01 and to be called HMS Queen Elizabeth. At 53,000 tons it would be the largest and most capable vessel ever built for the Royal Navy. ${ }^{7}$

Unfortunately the ship was never built. The navy proposals had aroused intense opposition from the Royal Air Force (RAF) who believed that British interests overseas could be better protected more cheaply through the application of land based airpower. ${ }^{8}$ A pressing requirement to find economies in the defense budget forced the new Labour administration to review Britain's defense posture. In a series of reviews between 1966 and 1968 British military commitments beyond Europe were reduced and then largely removed. CVA-01 was cancelled as was the RAF's favored alternative of $50 \mathrm{~F}-111 \mathrm{~A}$ strike aircraft. In future British conventional forces would

\footnotetext{
${ }^{4}$ For a more detailed examination of this period see I Speller, The Role of Amphibious Warfare in British Defence Policy, 1945-1956, (Basingstoke: Palgrave, 2001).

${ }^{5}$ Defence: Outline of Future Policy, Cmnd.124 (London, HMSO, 1957)

${ }^{6}$ I Speller, 'The Role of Amphibious Warfare in British Defence Policy, 1945-2000' in G Till (ed.), Seapower at the Millennium, (Stroud: Sutton Publishing, 2001) pp.88-89.

${ }^{7}$ UK Public Records Office, Kew [henceforth PRO]: ADM 1/29044. PRO:CAB 128/37, CC (63) 50 ${ }^{\text {th }}$

Conclusions, Cabinet Meeting on 30 July.

${ }^{8}$ PRO: AIR 8/2354.
} 
be concentrated in the European theatre and would focus on NATO tasks. ${ }^{9}$ It is notable that this process coincided with a re-emphasis by NATO on conventional forces in Europe with the introduction of the new concept of Flexible Response.

The reduction in the British military presence beyond Europe was initially to have been offset by the maintenance of a special capability for intervention. ${ }^{10}$ However, in a new round of cuts in January 1968 the government announced that no such capability would be maintained, only a general capability based on forces required for NATO duties was promised. ${ }^{11}$ The concentration on NATO tasks was reinforced by yet another defense review in 1975. In future UK defense policy would concentrate on four key areas: maintenance of the independent nuclear deterrent; direct defense of the UK homeland; a major land and air contribution to the European mainland; and, a major maritime commitment in the Eastern Atlantic and the English Channel. Remaining 'out of area' capabilities and commitments beyond NATO were reduced. It was indicative of the tone of this review that replacements for the two LPDs were removed from the Long Term Costings. ${ }^{12}$

This process reached its logical conclusion in the 1981 defense review conducted by the Conservative Minister of Defence, John Nott. Nott sought to control expenditure on defense by seeking the most cost effective means of meeting the existing four defense roles. He ruthlessly cut back expenditure on capabilities that did not meet his strict interpretation of British requirements. The review, published in June 1981 with the title 'The Way Forward', acknowledged that British defense concerns were not limited by the boundaries of the NATO treaty area. It sought a limited enhancement of out-of-area capabilities based on plans for a 'modest' stockpile of basic army equipment for contingency deployments and exercises, the designation of an existing headquarters to plan and command such operations and an increase in airlift and parachute assault capabilities. These modest enhancements were more than offset by the serious cuts in maritime expeditionary capabilities envisaged in the review. ${ }^{13}$

Nott appeared unconvinced of the value of a traditional balanced surface fleet with a range of capabilities. He believed that the navy's main task after provision of the national nuclear deterrent, that of anti-submarine warfare in the eastern Atlantic, could be most effectively conducted using nuclear powered submarines (SSNs), land based maritime patrol aircraft and a reduced number of surface escorts.

Expeditionary capabilities did not figure prominently in his vision for the future navy. Nott contemplated abolishing the Royal Marines but eventually decided only to scrap the specialist amphibious LPDs. ${ }^{14}$ In addition he announced the intention to sell the old aircraft carrier HMS Hermes and the first of three smaller Invincible class aircraft carriers. Frigate and destroyer numbers were to be reduced from 65 to 50 with eight of these ships in reserve. The Review anticipated a resumption of the practice of

\footnotetext{
${ }^{9}$ Statement on the Defence Estimates 1966. Part 1.The Defence Review. Cmnd. 2901 (London: HMSO, 1966). Supplementary Statement on Defence Policy 1967, Cmnd. 3357 (London: HMSO, 1967). Statement on the Defence Estimates 1968, Cmnd. 3540 (London: HMSO, 1968).

${ }^{10}$ Supplementary Statement on Defence Policy 1967, Cmnd. 3357 (London: HMSO, 1967)

${ }^{11}$ Statement on the Defence Estimates 1968, Cmnd. 3540.

${ }^{12}$ Statement on the Defence Estimates, 1975 CM. 5976 (London: HMSO, 1975)

${ }^{13}$ The United Kingdom Defence Programme: The Way Forward, Cmnd. 8288 (London: HMSO, 1982)

${ }^{14}$ A Dorman, 'Back to the Future: the Royal Navy in the Twenty-First Century' in A Dorman, M Smith and M Uttley (eds.), The Changing Face of Maritime Power, (Basingstoke: Macmillan, 1999) p.172.
} 
sending substantial naval task groups on long detachments for visits and exercises in the South Atlantic, Caribbean, Indian Ocean and Far East. However, such task groups would be used primarily for purposes of naval diplomacy and would not represent a balanced maritime force capable of projecting military power overseas.

In the event, the decision to scrap the LPDs was reversed before the Falklands Conflict and both vessels went on to play a vital part in British operations in the South Atlantic. Nevertheless the cuts proposed by Nott were the cause of serious concern within the Royal Navy. The Navy Minister, Keith Speed, was dismissed for opposing Nott's plans. ${ }^{15}$ The Nott Review was a response to and a reflection of an enduring dilemma within British defense policy. As a medium sized power with limited resources it was difficult for Britain to simultaneously meet alliance commitments in Europe and to maintain a military capability to support the country's many remaining interests, responsibilities and commitments beyond. 'The Way Forward' stated that Britain's 'needs, outlook and interests' gave it a 'special role and a special duty' beyond the boundaries of the NATO Treaty. ${ }^{16}$ In common with its predecessors the review did not conclude that this special role and special duty would require any special capability. With the exception of the modest enhancements outlined above, wider defense interests would be met by forces devoted primarily to NATO duties. The Falklands Conflict was to test the validity of this approach.

\section{The 'Lessons of the Falklands'}

The Falklands Conflict was viewed with great interest by commentators on both sides of the Atlantic. Even before the campaign was over pundits were trying to assess the 'lessons' that could be drawn from it. Within a matter of months the first books seeking to analyze the campaign had been published and they were to be followed by many more in the years that followed. ${ }^{17}$ The conflict was interesting for a number of reasons. It provided a rare insight into the performance of numerous weapons systems in actual combat. It also offered a chance to test tactics and techniques and provided a means of assessing the professional competence of the forces involved. The conflict was the first time since 1945 that a major western navy had come under sustained air attack at sea. It was the first time that a nuclear-powered hunter killer submarine conducted a successful attack on enemy surface units. The conflict provided the operational debut for the short take off and vertical landing Harrier and illustrated the strengths and limitations of the UK's new Invincible class aircraft carriers. It tested the ability of a modern, medium sized navy to conduct operations at extended range under attack by a relatively sophisticated foe in the arduous conditions of the South Atlantic. The results shed light on the UK government's claim that forces devoted specifically to NATO contingencies in Europe would also be capable of meeting defense needs beyond the NATO area.

\footnotetext{
${ }^{15}$ E Grove, Vanguard to Trident. British Naval Policy since World War II, (London: Bodley Head, 1987) pp.346-347.

${ }^{16}$ The United Kingdom Defence Programme: The Way Forward, Cmnd. 8288.

${ }^{17}$ For example see A Preston, Sea Combat off the Falklands, (London: Collins Williams Books, 1982). A Coll and A Arend (eds.), The Falklands War. Lessons for Strategy, Diplomacy and International Law, (Boston: Allen and Unwin, 1985). B Watson and P Dunn (eds.), Military Lessons of the Falkland Islands War, (Boulder: Westview Press, 1984). A Cordesman and A Wagner, The Lessons of Modern War. Volume III. The Afghan and Falklands Conflicts, (Boulder: Westview Press, 1990)
} 
The conflict was essentially maritime in nature. British victory depended on the Royal Navy gaining sufficient sea control to put ashore a landing force and to support it in the subsequent land campaign. The threat that the Argentine surface fleet posed to British operations was neutralized early in the conflict. The sinking of the ancient cruiser General Belgrano by the SSN HMS Conqueror on 2 May demonstrated a potent threat to which the Argentine surface fleet had no answer. As a result they did not venture beyond their own coastal waters for the remainder of the conflict. Argentine diesel/electric submarines were barely more successful. In April 1982 Argentina had three seaworthy boats, including two modern German-built Type209s. ${ }^{18}$ Unfortunately their torpedo armament was unreliable and there were no successful attacks on enemy shipping. One Argentine submarine, the Santa Fe, was disabled on the surface by British helicopters. Nevertheless, the British placed a great emphasis on anti-submarine warfare and the effort expended chasing false contacts demonstrated their concern in this field. ${ }^{19}$ Sea mines, a weapon with great potential given the lack of mine countermeasures vessels within the UK task force, were not deployed in any numbers except in the immediate vicinity of Port Stanley. ${ }^{20}$

The greatest challenge to British sea control came from the aircraft of the Argentine air force and navy. ${ }^{21}$ Ever since the sinking of the Israeli destroyer Eilat by Egyptian attack craft armed with anti-ship missiles in 1967 the threat of sea-skimming missiles to surface warships had preoccupied naval planners. Argentina possessed a small number of French built Exocet anti-ship missiles capable of being launched by air. The threat that they posed was one of the most pressing concerns for the British. ${ }^{22}$ In the event, one destroyer was sunk and another damaged by Exocet missiles, in the latter case by a land-based missile fired from a mobile launcher on East Falkland. In addition to this the merchant ship Atlantic Conveyor was also sunk, carrying with it most of the landing force's heavy lift helicopters. Three more warships and a Royal Fleet Auxiliary (RFA) were sunk by conventional bombs dropped at low level by the Argentine air force and eight warships and two RFAs suffered varying degrees of damage, although most remained operational. ${ }^{23}$

Despite these seemingly heavy losses the Argentine air force and navy failed in their attempts at sea denial. Neither of the two critical aircraft carriers were successfully attacked and the vulnerable amphibious and transport shipping unloading men and equipment in San Carlos Water remained unharmed. The loss of frigates and destroyers, while tragic in human terms, was certainly not without historical precedent. The escorts fulfilled their primary role and protected the critical assets of the task force, although the loss of Atlantic Conveyor demonstrated the dangers of concentrating important material in a single vulnerable ship. In many respects the British were lucky. The Argentine air force conducted their attacks with extraordinary bravery but were operating at the limits of their range, in a role for which

\footnotetext{
${ }^{18}$ D Brown, The Royal Navy and the Falklands War, (London: Arrow Books, 1989) p.113

${ }^{19}$ For example, see S Woodward, One Hundred Days. The Memoirs of the Falklands Battle Group Commander, (London: Harper Collins, 1992) p.142. Brown, The Royal Navy and the Falklands War, p.90 and pp 156-7.

${ }^{20}$ S Woodward, One Hundred Days. pp 201-203.

${ }^{21}$ The Argentine aircraft carrier 25 de Mayo flew off its complement of eight A-4Q Skyhawks on 5 May. Thereafter they operated from shore bases alongside the Navy's Exocet capable Super Etendards.

${ }^{22}$ Woodward, One Hundred Days, pp.223-224 + p.301.

${ }^{23}$ The Falklands Campaign: The Lessons, Cmnd. 8758 (London: HMSO, 1982) p.18
} 
they had little training or experience. Even so, the margin between success and failure was very narrow. Had all of the bombs that hit Royal Navy ships actually detonated then British losses would have been much heavier. ${ }^{24}$

The British air defense effort was undermined by a variety of factors. In common with their opponents, this was a role for which the Royal Navy was relatively illequipped. The absence of airborne early warning (AEW), the limited range, speed and numbers of fighter aircraft embarked and the indifferent performance of defensive missile systems designed to operate against high level Soviet bombers in the eastern Atlantic increased the vulnerability of surface ships to air attack. The presence of a large, conventional aircraft carrier equipped with fixed wing AEW aircraft and long range, supersonic fighters would have transformed this situation. Unfortunately the last British carrier that met this criteria, HMS Ark Royal, had been decommissioned in 1978. US commentators were not slow to note the dangers in operating beyond the range of land based air defense without the range of capabilities offered by a large aircraft carrier. $^{25}$

Despite the age of the key landing ships, and a reliance on merchant vessels for additional lift, the British were able to land No. 3 Commando Brigade at a time and place of their own choice and supported it, reinforced by the $5^{\text {th }}$ Infantry Brigade, throughout the subsequent land campaign. The landing at San Carlos illustrated the fact that an ability to assault a directly defended beach is not always required when alternative landing sites are available. Once ashore the landing force faced a range of challenges, exacerbated by the inclement weather and arduous terrain. The lack of an LPH reduced the helicopter lift and thus the tactical mobility of the landing force, a problem exacerbated by the sinking of the Atlantic Conveyor . Fortunately, if anything, Argentine ground forces possessed even less tactical mobility. The difficulty of supplying ground forces, particularly the provision of ammunition for the brigade's light artillery batteries, illustrated the logistic problems inherent in any amphibious operation. $^{26}$

\section{The Official Response}

The initial UK government interpretation of the 'lessons' of the conflict was published in December 1982 in the government White Paper 'The Falklands Campaign: The Lessons'. ${ }^{27}$ The paper placed a particular emphasis on the performance of key weapon systems, noting areas where improvements were required. In a sign of things to come, the paper acknowledged the vital importance of satellite communications in operations conducted at great distance from the UK and announced plans to acquire a new British military satellite and to provide a satellite terminal in all major warships.

The paper paid tribute to the training, motivation and professionalism of the British forces engaged and stressed that the specialist training of the Royal Marine

\footnotetext{
${ }^{24}$ Grove, Vanguard to Trident, pp. 363-371.

${ }^{25}$ Admiral H Train, 'An Analysis of the Falkland/Malvinas Islands Campaign' in Naval War College Review, Winter 1988. p.40.

${ }^{26}$ For a detailed account of the land campaign see J Thompson, No Picnic. 3 Commando Brigade in the South Atlantic: 1982, (London: Leo Cooper, 1992)

${ }^{27}$ The Falklands Campaign: The Lessons, Cmnd. 8758.
} 
Commandos in the landing force was 'a particularly significant asset'. In a similar vein it noted that the experience gained from peacetime amphibious training conducted by the Royal Navy and the Royal Marines in support of their role reinforcing NATO's northern flank had proven vital. Typically, the report used its concluding remarks about amphibious forces to reaffirm their NATO role rather than to emphasize any future role in out of area operations. Likewise, the inability of RAF Vulcan bombers to close Port Stanley airfield using 1,000-pound dumb bombs was used to demonstrate the need for the new JP 233 advanced airfield attack weapon intended primarily for use against the Warsaw Pact.

In the maritime environment the paper noted the important sea denial role played by Royal Navy SSNs and also the challenges posed by enemy diesel/electric submarines operating in shallow water. It reported on investigations into the survivability of warships and refuted the suggestion that the use of aluminum in their construction had contributed to the loss of any vessels. It did, however, promise additional means to improve the damage control capabilities of warships. The two aircraft carriers, HMS Hermes and HMS Invincible, were described as being effective and flexible command and control ships that also provided a good platform for air defense. However, the paper acknowledged that the lack of organic AEW was a 'severe handicap' against Argentine low-level air attacks. This problem would be remedied in part by the deployment in the carriers of Sea King helicopters equipped with Searchwater radars. This, in conjunction with steps to give the Sea Harriers greater range and payload capacity through the addition of larger drop tanks and additional weapons points, was deemed to represent a 'major improvement in our carrier borne air defence capability'.

The critical battle of the Falklands Campaign was waged between the ships and aircraft of the Royal Navy and the aircraft of the Argentine air force and navy. Quoting eight 'kills', the paper affirmed the value of the medium range Sea Dart missile. It neglected to mention the system's problems dealing with low flying aircraft or the fact that it was liable to be swamped by the arrival of large numbers of aircraft as it could not track and engage multiple targets. The utility of the Sea Wolf point defense system was also noted and the speed with which its software was adapted to deal with low flying aircraft in addition to the missiles that it was designed to counter was cited as a particular success. Nevertheless, the need for additional point defense systems was acknowledge and the paper noted that as an interim measure the US Vulcan-Phalanx gun system had been fitted to the carriers HMS Illustrious and HMS Invincible.

One area where the specific requirements of 'out of area' operations was noted was in the field of logistic support where it was recognized that a special stockpile would need to be created to cater for such contingencies. The value of long-range air transport and the need for a robust air-to-air refueling (AAR) capability was stressed. In a similar vein the vital role played by merchant ships taken up from trade (STUFT) in supplementing Royal Navy and Royal Fleet Auxiliary shipping was noted, as was the sterling work of the dockyards, civilian ports and UK industry in general in preparing the task force as a whole for operations in the South Atlantic.

The paper announced a number of programs designed to meet equipment shortfalls and to enhance capabilities where required. Some of these, such as additions to $5^{\text {th }}$ 
Infantry Brigade to improve its parachute capabilities or the designation of a two-star headquarters to command forces committed to out of area operations, had been announced prior to the conflict. New measures included the purchase of wide bodied tankers for AAR, additional Phantom F4-J fighters to replace aircraft sent to Port Stanley, additional Sea Harriers and Chinook medium lift helicopters and new point defense gun systems for the aircraft carriers, the LPDs and all of the navy's Type 42 air defense destroyers. Most significantly, the government reversed its decision to sell HMS Invincible to Australia and announced its intention to maintain a fleet of three Invincible class carriers in order that two should be available for deployment at short notice. The government also announced that front-line frigate and destroyer numbers would be maintained at 'about 55' compared to the 42 envisaged before the conflict. Equipment and vessels lost during the conflict would be replaced by new construction and, significantly, the cost of the war would not come from the Ministry of Defence budget but rather would be paid from the government's contingency fund.

The White Paper reaffirmed that government policy was for operations outside the NATO area to be undertaken by forces whose primary role was in support of the alliance. It went on to claim that the campaign showed that many elements of the armed forces had the basic characteristics of flexibility and mobility which made them well suited to respond to challenges beyond Europe. Capabilities were to be enhanced by the measures noted above but there would be no major change in the focus of defense policy.

The claim that the Falklands campaign demonstrated that forces devoted to NATO tasks could also meet out of area contingencies appears rather sanguine. In reality British victory was only possible because of the availability of several old platforms originally designed for operations beyond the NATO region and whose long-term future was open to some doubt. The old aircraft carrier HMS Hermes made a vital contribution to air operations. It was larger than the newer Invincible class and carried twice as many Harriers. The British were fortunate that this old ship, launched in 1953, was still available and had not yet been replaced by its diminutive successor. ${ }^{28}$ The amphibious landings would not have been possible without the specialist amphibious shipping built in the 1960s and already showing signs of age. Even modern general-purpose ships like frigates and destroyers were less well suited to supporting expeditionary operations than older vessels. The modern Type 42 destroyer and Type 21 frigate each had only one 4.5-inch gun, compared to two in the older County class destroyers and Type 12 frigates. The Type 42 and Type 21 were equipped with a more modern gun but the danger of relying on a single barrel for prolonged fire support became apparent when the frigate HMS Arrow (Type 21) designated to support the advance of 2 PARA on Goose Green developed a fault with its gun which stopped it firing. ${ }^{29}$ This problem was exacerbated as the gun armament in the Batch II and III Leander class frigates and the new Type 22 frigate had been removed entirely in order to make space for Exocet missile launchers. Clearly the ability to provide gunfire support for troops ashore had not figured prominently in their specifications. British forces demonstrated admirable mobility and flexibility

\footnotetext{
${ }^{28}$ At full load HMS Hermes displaced 28,700 tons compared to HMS Invincible which displaced 19,500 tons. For the Falklands Campaign Hermes embarked 15 Sea Harriers, 6 RAF GR3 Harriers and 9 helicopters while Invincible embarked 10 Sea Harriers and 10 helicopters. Brown, The Royal Navy and the Falklands War, p. 358.

${ }^{29}$ Thompson, No Picnic, p.76
} 
during the Falklands Conflict. Whether they would have done so without the ageing legacy of a previous capability is doubtful.

\section{Implementing the Lessons.}

One of the most striking features of the Falklands Conflict is just how little impact it had on the general direction of British defense policy. Despite the changes noted above, The Lessons of the Falklands Campaign explicitly stated that the defense policy adopted in the 1981 review was extant. ${ }^{30}$ The four key roles adopted in 1975 remained unchanged. Unlike Suez in 1956, where failure reinforced the need for change, victory in the Falklands appeared to confirm the government's claim that remaining out of area commitments could be met by forces devoted primarily to NATO duties. All that was required were a limited number of force enhancements, some of which had been anticipated prior to the war.

The main focus for defense policy remained the strategic nuclear deterrent, home defense, a major land and air contribution to the defense of the European mainland and a maritime capability in the Eastern Atlantic and Channel. A typical explanation of British policy was provided in the 1985 Statement on the Defence Estimates, which made it clear that:

NATO commitments will remain our overriding priority; and our ability to act outside the NATO area will be based on ensuring that selected units whose primary roles are within the Alliance can also deploy rapidly at long range in a crisis. $^{31}$

Within this approach airborne forces, unused in their primary role since $1956^{32}$, fared rather better than amphibious capabilities. John Nott had decided to increase Britain's airborne capabilities prior to the Falklands Conflict. Plans were made to increase the RAF's air transport capability by 'stretching' 30 Hercules transport aircraft. The decision was also taken to install special station-keeping radar equipment to enable aircraft to carry out the coordinated drop of a parachute assault force in poor weather. $^{33}$ In 1984 it was announced that the $5^{\text {th }}$ Infantry Brigade would receive a number of force enhancements, including an air defense troop and further signals, medical and logistics units. The parachute capability of the brigade was to be increased to include the light gun regiment, the air defense troop and the integral logistic support units in addition to the parachute battalions of the Parachute Regiment. ${ }^{34}$ In view of these enhancements the brigade was renamed 5 Airborne Brigade. By 1986 the government was able to announce that the UK was now 'better able to launch a rapid and effective battalion group parachute assault, if the need ever arises'. ${ }^{35}$

\footnotetext{
${ }^{30}$ The Falklands Campaign: The Lessons, Cmnd. 8758.

${ }^{31}$ Statement on the Defence Estimates, 1985. Part One, Cmnd. 9430-I (London: HMSO, 1985) p.11

${ }^{32}$ Airborne forces played no part in the Falklands Conflict except on foot as part of No.3 Commando Brigade.

${ }^{33}$ Statement on the Defence Estimates, 1982. Part One, Cmnd. 8529-I (London: HMSO, 1982) pp. 1619. This White Paper was written prior to the Falklands Conflict and published unchanged after it had ended.

${ }^{34}$ Statement on the Defence Estimates, 1984. Part One, Cmnd. 9227-I (London: HMSO, 1984) pp.3233.

${ }^{35}$ Statement on the Defence Estimates, 1986. Part One, Cmnd. 9763-I (London: HMSO, 1986) p.38
} 
Just as the UK approach to airborne capabilities remained unchanged by the Falklands Conflict, so did the approach towards amphibious capabilities. The primary role of UK amphibious forces remained the reinforcement of NATO's Northern Flank in the event of a Soviet attack. The two old LPDs had been reprieved prior to the conflict and both were retained after 1982, with one in service and the other in refit or on standby. However, there were no plans to replace these ageing vessels nor were there any plans to build a dedicated helicopter assault ship to replace the commando carrier capability lost when HMS Hermes was sold to India in $1986 .{ }^{36}$ War loses were made good with the construction of a new ship to replace the LSL Sir Galahad lost at Bluff Cove, but it was clear that the amphibious fleet of the future, should it be maintained at all, would be based on ships built in the 1960s.

The most obvious way in which maritime expeditionary capabilities benefited from the Falklands conflict was in the retention of all three Invincible class aircraft carriers. The sale of HMS Invincible, still envisaged in the 1982 Defence White Paper, was cancelled and the Royal Navy maintained a force of three aircraft carriers, with two in service, throughout the 1980s. Shortcomings in AEW were partially rectified by the deployment of Sea King helicopters equipped with Searchwater AEW radar.

However, in common with the rest of the Royal Navy, the carrier's main tasks were associated with the battle for sea control in the eastern Atlantic, the English Channel and in northern waters providing ASW support for the NATO Strike Fleet.

Despite the explicit focus on Europe the Royal Navy maintained a presence beyond the NATO area. A small patrol of escort vessels was maintained in the Persian Gulf in order to provide for the security of British shipping in that region. Royal Navy ships continued the practice of conducting exercises and port visits around the globe. Inevitably, the Falkland Islands now featured in the navy's pattern of deployment with periodic visits by destroyers, frigates and SSNs. However, in line with policy before 1982, the main focus of major naval deployments beyond the NATO area was the Indian Ocean and the Far East rather than the South Atlantic. The first major Task Group deployment after the war occurred between September 1983 and April 1984 when a Task Group based around the aircraft carrier HMS Invincible undertook a program of exercises and visits in the Indian Ocean, the Far East and the South Pacific. $^{37}$ Subsequent major deployments were to follow a broadly similar pattern. The Falklands Conflict did not change the main focus of Britain's maritime activity beyond Europe.

\section{Back to the Future.}

The basic nature of British defense policy did not change as a result of the Falklands conflict. Europe and NATO remained the priorities, with out of area contingencies met by forces primarily devoted to NATO. A number of force enhancements did occur due to the experience of 1982, most notably the retention of two rather than three small aircraft carriers. However, many of the changes, such as the fitting of point defense gun systems to major surface vessels, reflected tactical lessons about the vulnerability of warships to missile attack rather than any strategic reevaluation. A major sea change in British defense priorities did not occur until the end of the decade

\footnotetext{
${ }^{36}$ HMS Hermes had a dual role as an aircraft carrier and a commando carrier/LPH.

${ }^{37}$ Statement on the Defence Estimates, 1984. Part One, Cmnd. 9227-I (London: HMSO, 1984) p.32
} 
when the disintegration of the Warsaw Pact and then of the Soviet Union itself brought a fundamental change in the strategic environment.

The UK government's most basic response to these changes was to seize the opportunity to reduce the defense budget. Over the 1990s defense spending fell by some twenty per cent. ${ }^{38}$ Within this constraint British defense policy was now characterized in terms of three main defense roles:

1. Defense Role One: home defense and defense of the dependent territories

2. Defense Role Two: defense of Europe through NATO

3. Defense Role Three: peacekeeping, out-of-area responsibilities

In reality defense role two remained the key role for Britain's armed forces and this was reflected in the commitment of two divisions and a headquarters to the new Allied Command Europe Rapid Reaction Corps. The costs of maintaining a major force in mainland Europe, allied to the reductions in the defense budget, made it difficult for the government to meet its declared aim of making UK forces more flexible, deployable and sustainable. ${ }^{39}$

By this time the issue of replacements for the navy's ageing amphibious ships had become urgent. As early as 1985 the Ministry of Defence had announced that it was investigating a range of options for providing a future amphibious capability. In 1986 it was reported that $£ 450$ million had been set aside in the Long-Term Costings to cover the modernization of both LPDs together with the possible conversion of two container ships into helicopter equipped commando carriers. ${ }^{40}$ Swan Hunter Shipbuilders was awarded a contract to examine the feasibility of a service life extension program (SLEP) to allow the two LPDs to remain in service beyond the mid-1990s. ${ }^{41}$ Progress was slow. The 1988 and 1989 Defense White Papers both noted that these feasibility studies were underway but did not commit the government to any action. ${ }^{42}$

Further progress did not occur until the end of the Cold War brought a slow change in the focus of defense policy. In 1991 the government announced its intention to 'replace and improve' the Royal Navy's amphibious shipping and in 1992 a £2.5 million contract was awarded for a project definition study for Landing Platform Dock (Replacement) (LPD(R)). ${ }^{43}$ Despite serious fears that these ships might fall prey to Treasury imposed cuts, invitations to tender for LPD(R) were issued in August 1994 and in July 1996 Vickers Shipbuilding and Engineering Ltd (VSEL) was awarded the contract to build two ships to replace HMS Fearless and Intrepid. ${ }^{44}$ The two ships, to adopt the old commando carrier names HMS Albion and Bulwark, were to enter service in 2001 and 2003 respectively, although subsequent delays mean that the first ship will not enter service before 2003.

\footnotetext{
${ }^{38}$ L Freedman, The Politics of British Defence1979-98, (Basingstoke: Macmillan, 1999) p. 96.

${ }^{39}$ A Dorman, 'Reconciling Britain to Europe in the Next Millennium: The Evolution of British Defense Policy in the Post-Cold War Era' in Defense Analysis Vol. 17, No. 2, 2001, pp187-22.

${ }^{40}$ Grove, Vanguard to Trident, p. 386

${ }^{41}$ Warship World Vol. 3, No.6 Spring 1990 p.4

${ }^{42}$ Statement on the Defence Estimates 1989. Volume I. Cm 675-I. (London: HMSO, 1989) p.24

${ }^{43}$ Warship World Vol 4 No.2. Spring 1992 p.8

${ }^{44}$ Jane's Navy International, Vol. 101 No. 7, September 1996.
} 
Significant progress was also made with other aspects of the amphibious capability. In 1986 the government announced plans to procure two new Aviation Support Ships. Tenders were invited in October 1988 and bids were received from three consortia. Unfortunately budgetary provision proved inadequate and the project was shelved. It was revived after the 'Options for Change' defense review and invitations to tender were issued in February 1992. The project remained blighted by budgetary constraints despite the reduction in scope to only one vessel, now described as an LPH. Operations in the Adriatic off the Former Republic of Yugoslavia in early 1993 demonstrated the difficulties of conducting helicopter operations from inadequate shipping and this, allied to concerns about the financial position of some British shipyards, may have helped to revive the procurement process. In May 1993 VSEL was awarded the contract to build a new LPH costing $£ 143.9$ million and to be christened HMS Ocean. This ship was commissioned in $1998{ }^{45}$

The third component of the amphibious fleet was the five Landing Ship Logistics (LSLs) operated by the Royal Fleet Auxiliary. Of these, one (Sir Galahad) had been built after the Falklands Conflict to replace the original lost at Bluff Cove and another (Sir Tristram) had undergone a major re-build in order to make good damage sustained in the same attack. A third ship (Sir Bedivere) underwent a SLEP refit from 1994-1998 to extend its useful life by a further 15 years. Unfortunately the excess cost and disappointing results of this process resulted in the cancellation of similar SLEP refits for the two remaining LSLs (Sir Geraint and Sir Percivale). It was decided, instead, to replace these two ships with new larger and more capable Alternative LSLs (ALSLs). ${ }^{46}$

Maritime expeditionary capabilities were enhanced in a variety of other ways. The value of traditional naval gunfire was demonstrated during the Falklands conflict, where navy 4.5-inch guns provided vital fire support for ground forces and proved to be an effective anti-surface warfare weapon against Argentinean supply vessels. Prior to the conflict there had been a trend to replace these guns with missile systems such as the Exocet missiles fitted to the early Type- 22 frigates. After the conflict the value of the gun was recognized and Batch III Type-22 frigates and the new Type-23 frigates were all fitted with a 4.5-inch gun in addition to their missile armament. More remarkably, the government announced the purchase of 65 Tomahawk Land Attack Missiles (TLAM) from the United States. ${ }^{47}$ These missiles, to be fired from SSNs, would provide the British with a long-range precision strike cruise missile capability. For the first time, Royal Navy SSNs would have a significant power projection capability.

Perhaps the biggest test of UK attitudes towards maritime expeditionary capabilities came with the case for the aircraft carriers. As noted above, the Falklands Conflict led to the retention of all three Invincible class aircraft carriers, although with only two air groups. There were no plans to replace these small ships with larger, more capable vessels. The primary role for the carriers remained that of providing ASW support to the NATO Striking Fleet, with any expeditionary capability coming as

\footnotetext{
${ }^{45}$ R Scott, 'Ocean's wave is set to roll' in Jane's Navy International, Vol. 104 No. 4, September 1999.

46 'RFA crucial in expeditionary warfare' in Jane's Navy International January/February 2001. pp.1923.

${ }^{47}$ Dorman, 'Back to the Future’, p.167.
} 
something of a bonus. With the end of the Cold War and the emergence of new challenges beyond continental Europe this secondary role became their primary rationale. UK carriers found gainful employment in support of British policy in the Adriatic and the Persian Gulf. In order to boost the power projection capability of these vessels RAF ground-attack Harrier GR7s were embarked in addition to the normal complement of Sea Harriers. The Sea Harriers themselves underwent a major upgrade, receiving new radar, avionics and advanced missiles. In order to provide more space on deck and to give more internal space for equipment and ammunition all three ships had their Sea Dart area-air-defense missile systems removed. These measures combined to make the three carriers much more capable power projection platforms than was the case in 1982. However, their limited size restricts both the number and type of aircraft that can be embarked. ${ }^{48}$ These ships were not designed as power projection platforms and their limitations have become apparent in recent operations.

In 1997 a new Labour administration was elected after 18 years of Conservative rule. On taking office the new government undertook a major reevaluation of UK defense policy. Its aim was to set a blueprint to modernize and reshape the armed forces to meet the challenges of the twenty-first century. The result was the 1998 Strategic Defense Review (SDR). The SDR reflected, reinforced and codified existing developments in British defense policy. It emphasized that there was now no direct military threat to the UK or Western Europe and, while this situation could not be taken for granted, there was a greater need to meet security challenges on the fringes of Europe and beyond. The paper placed a firm emphasis on mobile, flexible and deployable forces able to meet the diverse challenges of the future. The Minister of Defense, George Robertson, succinctly summed up future requirements by stating that 'In the post Cold War world, we must be prepared to go to the crisis rather than have the crisis come to us'. ${ }^{4}$

The SDR announced significant reductions in maritime capabilities as the threat of large-scale open-ocean warfare was seen to have receded. The SSN fleet was to be reduced from 12 to 10 boats. The total number of destroyers and frigates were reduced from 35 to 32 vessels and a planned increase in mine countermeasures vessels was reduced from a total of 25 to 22 hulls. The purchase of new EH 101 Merlin anti-submarine warfare helicopters was limited to 44 and the RAF's Tornado aircraft were to withdraw from the anti-shipping role. ${ }^{50}$

To counter-balance these reductions the SDR announced that the focus for maritime forces in future would be rapid deployment operations. The Invincible class carriers were to be given a wider power-projection role by the development of a Joint Force 2000 combining Royal Navy and RAF Harriers under one command. In future both types would operate from the carriers as required. ${ }^{51}$ Most significantly, the SDR

\footnotetext{
${ }^{48}$ After the removal of their Sea Dart systems the carrier's air complement can include eight FA2 Sea Harriers and eight RAF GR7 Harriers in addition to AEW and ASW helicopters. R Sharpe, Jane's Fighting Ships 2000-2001, (Coulsdon: Jane's, 2000) p. 754. This is still rather less than the air group deployed on HMS Hermes in 1982.

${ }^{49}$ The Strategic Defence Review, Cmnd. 3999, (London: HMSO, 1998) Introduction para.6.

${ }^{50}$ Ibid. chapter 7.

${ }^{51}$ In a move designed to increase British power projection capabilities on 28 February 2002 the Ministry of Defence announced that in future and prior to the arrival of the Future Joint Combat
} 
announced plans to replace the existing three aircraft carriers with two larger vessels from around 2012. At 30,000 - 40,000 tons these new ships would be up to twice the size of HMS Invincible and would be capable of deploying up to 50 fixed and rotary winged aircraft. Expeditionary capabilities were further reinforced by the decision to fit all SSNs to fire TLAM, the decision to continue the construction of the two LPD(R)s and the potential deployment of army WAH-64 Apache Longbow attack helicopters on HMS Ocean. ${ }^{52}$

Contemporary British defense policy has an overtly expeditionary focus. The armed forces have adopted the Joint Rapid Reaction Forces concept based upon a flexible pool of powerful and adaptable units and capabilities from all three services that can be put together to meet particular circumstances. ${ }^{53}$ The emphasis is on mobile, flexible and deployable forces. The ability of the Navy and Royal Marines to exploit joint assets such as RAF GR7 Harrier and Army attack helicopters should greatly enhance maritime expeditionary capabilities. Contemporary naval doctrine articulates a case for the navy as a key enabler for future joint operations. The Royal Navy Strategic Plan for the period 2000-2015 declares that:

The emphasis will be on expeditionary and littoral warfare, and our contribution to joint and combined operations, particularly at small and medium scales of effort. ${ }^{54}$

The Royal Marines have an important role to play within this concept and are currently reconfiguring under the Commando 21 initiatives in order to be able to meet future challenges. ${ }^{55}$ Current doctrine, evolving under the concept of 'Littoral Manoeuvre', reflects contemporary US ideas about expeditionary operations such as ship to objective maneuver, sea basing, and over the horizon operations, albeit on a reduced scale commensurate with British capabilities.

\section{The Lessons of the Falklands Conflict?}

In 1978 HMS Ark Royal, the navy's last large conventional aircraft carrier, was decommissioned. The decision to scrap such vessels had been supported by the following statement in the 1966 Defense Review:

Only one type of operation exists for which carriers and carrier borne aircraft would be indispensable; that is the landing or withdrawal of troops against sophisticated opposition beyond the range of land-based air cover. It is only

\footnotetext{
Aircraft in 2012 only one type of Harrier would be maintained. Thus, from around 2006 Joint Force Harrier will deploy the GR9, an updated version of the GR7 and the FA2 Sea Harrier will be withdrawn from service. This will enhance the ground attack capabilities of the carrier air groups but may seriously reduce the fleet air defence capabilities of the carriers as, unlike the FA2, the GR9 lacks radar and will only be equipped with short-range air-to-air weapons for self defense. In a development somewhat reminiscent of decisions taken in the 1960s, the fleet will be reliant for air defence on the surface to air missiles of the new Type-45 destroyers currently being developed. (Jane's Defence Weekly, March 01 2002)

52 Ibid.

53 'Joint Rapid Reaction Forces - Special Report', in Defence Review Winter 1998, pp.38-48.

${ }^{54}$ Navy Strategic Plan 2000-2015, www.royal-navy.mod.uk. downloaded 14 January 2002.

55 'Commando Units to be Reshaped’ in Navy News, January 2001. pp 1-2.
} 
realistic that we, unaided by our allies, could not expect to undertake operations of this character in the 1970 s. $^{56}$

Sixteen years later, and only one year after the Nott review had confirmed the basic logic of this decision, the British launched a brigade sized amphibious operation against sophisticated opposition beyond the range of land-based air cover and without the direct aid of allies.

It would be unfair to criticize the culmination of 16 years of British defense policy on the basis of a conflict that was as unexpected as it was unusual. Nevertheless, the conflict did illustrate a key weakness in British defense planning at this time. In order to devote limited resources to seemingly vital NATO roles, capabilities for action beyond Europe were progressively reduced without an equivalent reduction in commitments. Notwithstanding the modest increases announced prior to 1982, out of area contingencies would be met by forces devoted to the alliance. This was based upon the assumption that forces devoted to NATO would have sufficient mobility and flexibility to meet challenges overseas. Superficially, success during the Falklands Conflict appeared to support this case. However, in reality, British victory was far from certain. A slightly more capable opponent or perhaps a luckier one might have been able to exploit more successfully the serious weaknesses in some areas of the British task force. In many respects British success rested a number of old 'legacy' platforms whose future had been open to some doubt. Despite this, the experience of 1982 did not cause the government to change its view that it did not require a special military capability for intervention overseas.

Twenty years later the UK places a much higher priority on maritime expeditionary capabilities. One may question the extent to which this is a result of the 'lessons of the Falklands Conflict'. The war certainly provided a useful insight into the performance of particular weapon systems, tactics, and the design of warships but it did not prompt a major strategic reappraisal nor did it solve the enduring problem of resources. In reality the current British focus on expeditionary operations is a result of a change in strategic priorities that was entirely unconnected to the Falklands Conflict. Likewise, contemporary doctrine is influenced by a general body of experience that includes the events of 1982. However, neither contemporary British nor US doctrine has its origins in the 'lessons' of that conflict. Rather they reflect an appreciation of the potential of new and evolving technologies to radically alter the way in which navies operate, both offensively and defensively, allied to an understanding of the changing political context within which military force will be applied. In a manner reminiscent of the early 1960s, British defense policy has seized the opportunity presented by stability in Europe to meet the challenge posed by instability elsewhere. Shorn of the Soviet threat, the armed forces no longer struggle to meet world-wide commitments with forces designed primarily for major war in Europe. Rather, both procurement and doctrine reflect a primary emphasis on the requirements of expeditionary operations. For the first time in thirty years British defense policy once again recognizes the requirement for a 'Special Military Capability' for intervention overseas. The result is likely to be a significant enhancement in expeditionary capabilities in general, and maritime expeditionary capabilities in particular.

\footnotetext{
${ }^{56}$ Statement on the Defence Estimates 1966, Cmnd 2901.p.10
} 
Despite this, the key problem of resources remains. The announcement in February 2002 that in future, prior to the arrival of the Future Joint Combat Aircraft in 2012, only one type of Harrier would be retained, illustrates an enduring problem. The technical and logistical problems of maintaining and updating two different types of Harrier have proven to be beyond British resources. Thus, from around 2006 Joint Force Harrier will deploy the GR9, an updated version of the RAF GR7 and the FA2 Sea Harrier will be withdrawn from service. This will enhance the ground attack capabilities of the carrier air groups making them more effective power projection platforms when there is not a significant air threat. However, the decision may seriously reduce the fleet air defence capabilities of the carriers as, unlike the FA2, the GR9 lacks radar and will only be equipped with short-range air-to-air weapons for self defense. In a development somewhat reminiscent of decisions taken in the 1960s, the fleet will be reliant for air defence on the surface to air missiles of the new Type45 destroyers currently being developed. (Jane’s Defence Weekly, March 01 2002) 